\title{
An ecological and morphological study on (Asplenium scolopendrium) Phyllitis scolopendrium (L.) .Newman within Howler (Erbil) City - Kurdistan of Iraq
}

\author{
Abbas M. Ismail*, Baram K. Maulood** and Talib O. AL- Khasraji**** \\ *Baghdad Univ. College of science for women \\ **Sallahaldin Univ. College of science \\ $* * *$ Tikrit Univ. College of Education for pure science
}

\begin{abstract}
The present investigation deals with morphological and ecological study of the fern Phyllitis scolopendrium the haerts -toungue fern (Asplenium scolopendrium) (Scolopendrium vulgare) within Malakan area in Erbil province ( Kurdistan of Iraq) during years 2014-20152016. Some environmental parameters (soil PH, soil texture, cat ions and anions) were considered. Also Ferns morphology, habitat, sporophyte, sori and spores were described. Different measurement of various part of plant was performed. This study may be the first attempt to such detailed study on Phyllitis and even ferns in Kurdistan and Iraq as whole.
\end{abstract}

Keywords: Aspleniaceae, Ferns, phyllitis, Heart's-tongue.

\section{Introduction}

Natural environment comprises of both biotic and abiotic components, of the biotic component, plants play an important role on earth surface, without which other living system cannot survive. About 250 million years ago were the dominant plant group on this planet, (Sathiyaraj et al, 2015). Pteridophytes evolutionary may be regard as the first group appeared on land (terrestrial plants) and said to be primitive vascular cryptogams (ferns and fern allies), shade loving plants from the dominant vegetation on the earth (Benniamin, 2011), that include small shrub like up to large trees that range reach up to few meters high, still there are few aquatic fern species those known even in Iraq such as Azolla, Salvinia, Marselea (Townsend \& Guest, 1966 and AL-Mayah, 2015). Pteridophytes are those vascular plants those not produces seeds, flowers, and fruits, they are known as cryptogamic vascular plant (Smith, 1955).

Fern reproduce through spores, that produced within sori Alternation of generation in this group of plants dominated by large and predominant sporophyte (2n) whereas gametophyte (1n) is small in size and heart- shaped called prothallus (Lowe \& Bumflek, 2002 ). 
Sporophyte may be Homosporous or Heterosporous (Smith et al, 2006) For the best of our knowledge, there is no any detail comprehensive study on any species or genus of ferns in Iraqi Kurdistan region or Iraq as a whole (Maulood et al ,2016) . Most plant studies in Iraq was concenterated on flowering plants in respect to taxonomy and morphology whereas Non flowering plants reveal quit little attention apart thallophytes from( algae and fungi ) (Maulood et al , 1990). After a gap of about 50 years since 1966 by which Townsend \&Guest and AL-Rawi represented in (Townsend \& Guest, 1966) who have done a good work and had given are relating to pteridophyta flora of Iraq (Aziz, 2017) Studies on bryophytes on the other hand is confined to almost only general references such as (AL-Rawi ,1964, Townsend and Guest 1966, and Chakravarty, 1976). The work of (AL-Nima, 2003) may be regarded as first comprehensive study on Bryophytes in Iraq. However few anatomical and cytological studies on some aquatic ferns in Iraq were performed (Yaqub, 1989, and AL-Maqdamy 2008). Recently ferns studies in Kurdistan of Iraq, concenterated on geographical distribution of pteridophytes and Equisetum species and its distribution and morphological description ( Salih, 2014 , Maulood et al, 2016 and Aziz, 2017). Many memberes of pteridophytes has an economical importance still their toxicity is also known poisonous (AL-Rawi, 1988). Other have important role in mineral recycling and soil treatment Marsh et al, (2000). The present paper is dealing with Phyllitis a genus that have not received any attention to deal with scientifically so far in Iraq. The morphological description and habitat were described in present study for the first time ultimately this paper hopefully will follow by similar investigation on other known ferns in Kurdistan by the authors or others soon as later.

\section{Description of study area}

Malakan is an area situated along head of khlaifan river $74 \mathrm{~km}$ North west of Erbil city ,Fig.(1) shows that Malakan is located at $558 \mathrm{~m}$ above sea level at latitude E 4426533 and longitude N 3637496 , a water chanal passes through the area, weed forests ,hedge banks common, with climate is cold in winter from October to April with winter rainfall while, the Summer season is hot and dry, the rocks of hills and mountains are of calcareous type, (Townsend \& Guest, 1966 and Guest \& AL-Rawi ,1966). Malakan is one of the most attractive area for tourism in the region. This fern was confined to this area as tufted winter green fern, the plant is so distinct in its general appearance there is little chance of confusion arising. 


\section{Methodology}

Plant species have been collected throughout years 2014, 2015, 2016 during months of AprilOctober from different habitats all over the area .Photograph of the plant with various size and habitat were taken in the field. Samples in the field were examined using hand lens and all measurements of leaflets, sori, rhizome, roots and general morphology have been measured and studied in the field, all results were from fresh samples, the less GPS were used for measuring latitude and altitude, all measurement were don then after, all measures carried out again on return to Howler Botanical Garden, to record all morphological measurements . Then samples were divided to three groups as follows:

Group one samples were separated and pressed in Howler Botanical Garden then preserved in Kurdistan herbarium in Erbil and has dimensioned of WP. 21/59. The second group on the other hand were preserved in FAA solution for more different studies. The third group used for detailed studies of fronds, rhizome, root. Reproduction organs (sori) were examined using compound microscope. Photographs of all areal parts of the plants were taken as well as rhizomes and roots, then after measurement and photographs of sori as well as sporangium and spores were recorded. Soil properties were examined according to Goerge \& Jhon(,2013 ), all factors were estimated in labs of Ministry of science and Technology as well as Ibn-al Haithum central lab in Ibn-al Haithum college of pure science / Baghdad University .

Taxonomy and identification of the plant were according to Smith et al (2006) as follows: Plantae, Pteridophytes, Polypodiopsida, Polypodiales,Aspleniaceae, Phyllitis, scolopendrium L. ( Asplenium scolopendrium ) (common name Heart tongue fern) .

\section{Results:}

Morphological studies and measurements were estimated a result of an average of 25-45 specimen from each of different localities within Malakan area. Phyllitis species were collected randomly, the results represent samples from different period of time between Feb. to Jun. of the years 2014-2015-2016. The results as follows:

- Length of the plant: 25-30 may be reached $40 \mathrm{~cm}$.

- Length of the frond: $15-20 \mathrm{~cm}$ and the width $2-4 \mathrm{~cm}$.

- Length of petiole: 8-10 may be reached $12 \mathrm{~cm}$.

- Length of rhizome: $0.5-1.5 \mathrm{~cm}$ and the root $3-5 \mathrm{~cm}$ in length.

- Brunches from rhizome: 30-40 may be reached 50 brunch. 
- Sori number around the midrib: 24-40 sorus.

In respect to the frond, it was simple, narrowly oblong, undivided, from a somewhat heartshaped base , bright green color, fruit-dots linear, elongated, a raw on either side of the midrib and at aright anglitoid, its variable in size $10-45 \mathrm{~cm}$ long up to $8 \mathrm{~cm}$ wide arising erect and strongly curved out word and down words fig (2) .

Leaves are characterized with wavy margin with pointed ends and heart shape base low-end inside. Leaf raised from rhizome as at tuft through the stout (which is covered when young with soft white hairs becoming light brown or reddish brown midrib) uprising from abdominal side of lower epidermis and twisted slightly toward upper epidermis. The venation in clearly penalty reticulate and the veins are dichotomously ( they are known to be taenopteridi ) brunched and ends are alternately brunched and unbrunched fig (2). The blade very variable $5-35 \mathrm{~cm}$ long up to $8 \mathrm{~cm}$ wide more typically about $15-20 \mathrm{~cm}$ long and no more than $5 \mathrm{~cm}$ wide typically, simple strap- shape (linear-lanceolate ) out line typically a pen pointed, occasionally more or less digitated or crests, margin wavy .

The leaf is generally smooth in both sides while the petiole is hairy with large number of trichome. Sori linear are situated in pairs along both sides of the main vein in arrow to form a cigar shaped mass with a distance form at twise with a distance from outer margin of the leaf often covering most of the upper part of the blade. The rhizome short and spherical whereas roots are long and with dense root hair fig (2).

Reproductive organs have been examined using compound light microscope with different magnification. The results indicated that sori are brown in color arranged in pairs short and long alternation. Sporangium under light microscope show spherical oblong shape with diameter about 150-170 micrometer with about 20-22 cells consisting the annulus with about 28-30 micrometer thick, the spores on the other hand inside the sporangium with wavy wall with length 30x36- 35x40 micrometer .

As far as its habitat of the plant was found within shaded ravines under calcareous and limestone cliffs, along water channel in Mallakan which can be described as woody forests, hedge banks, commonly are on the rocky walls. They appear in dense cluster of 2 Inch up to feet or more long with stalks which are below and often to the base of the leaf fig (3).

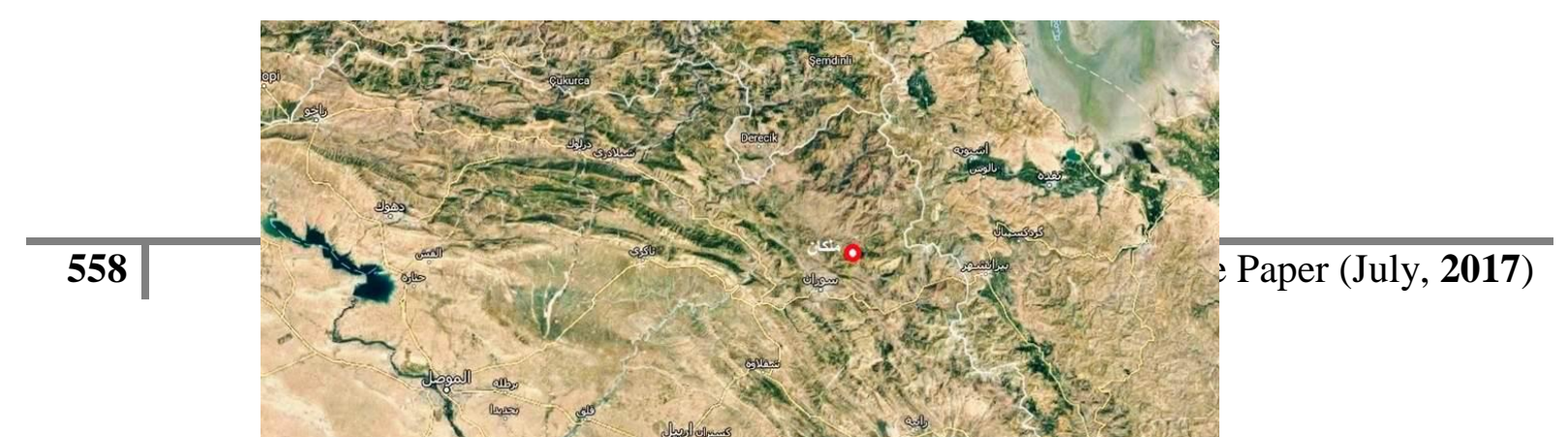




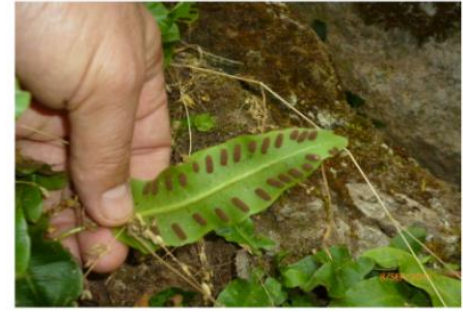

(a)

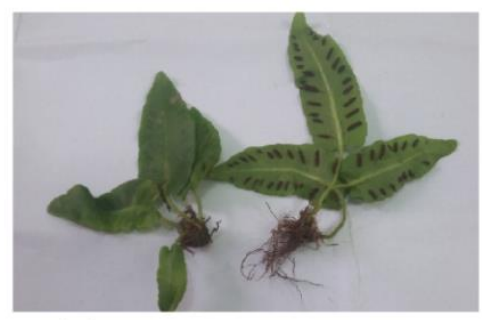

(c)

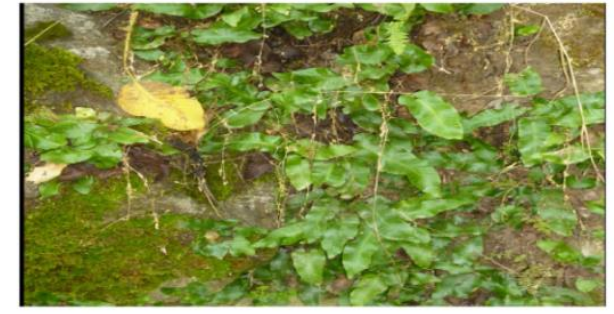

(b)

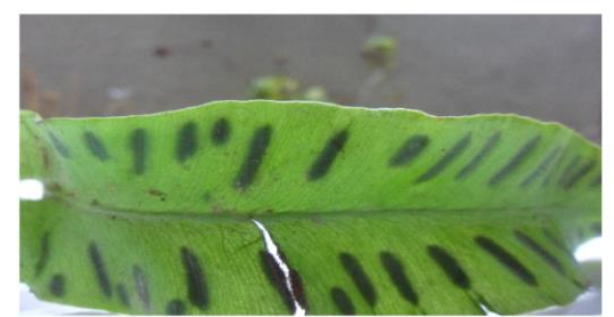

(d)

Fig 2: (a) Fronde with sori (b) Plant habitat (c) Whole plant (d) Leaf venation.

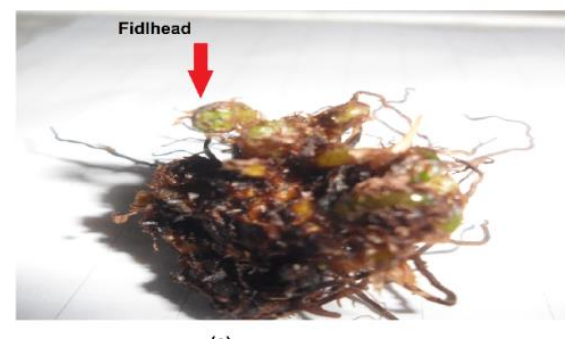

(a)

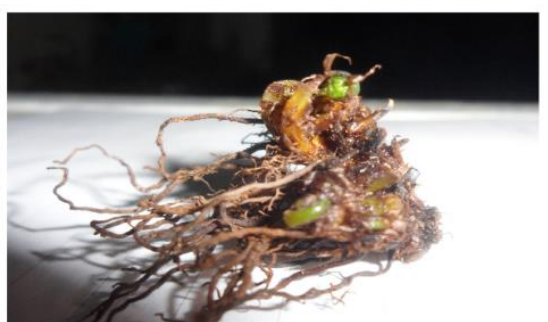

(b)

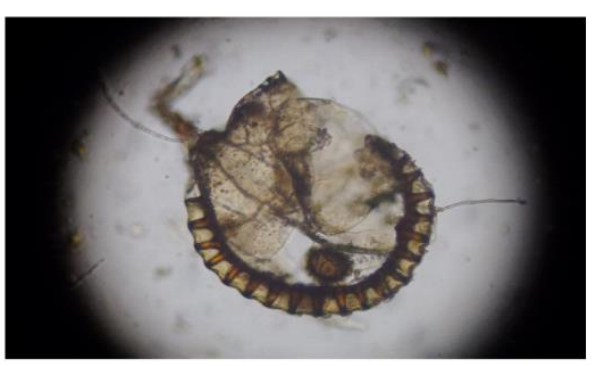

(c) 
Fig 3: (a) Rhizome with fiddlehead (b) Rhizome with roots (c) Sporangium with spore.

\section{Discussion}

Phyllitis is normaly narrowly found among other ferns and mosses its generally known as Haerts tongue (Asplenium scolopendrium, Scolopendrium vulgar) as it not widly distributed and so far was not recorded in Kurdistan but in Malakan. This can be contrasted with its distribution in U.S.A as it`s restricted to areas such as Casanaia in N.Y and they describe the fern as very rear (Parson, 1961 and Mickel, 2003). However Grounds,(1974) refer to this fern a one of the commonest ferns in Europe, north Africa, its also recorded in minor Asia and Persia , Japan. The plant may resist various climatic factores in respsct to temperature and even in frostry areas wher the laevs remain green during Winter season till the growing season that start during May, it is reproduce by spores . Many parameters were estimated during the present investigation as mentioned above. Soil $\mathrm{pH}$ ranged from 7.8-8.0 this come in accordness to (Currie, 2010, and Futyma, 1980 ), whereas soil texture was loamystone and the Carbonats content( 300 ppm) was reflected in the alkalinity of the soil (APHA ,2005). Nitrate and Phosphate level in soil were 1.1 and 2.3 ppm respectively, whereas Calcium and Magnsium, were $(32,24 \mathrm{ppm}$,) respectively. Phyllitis is one of the easiest fern to grow provided the soil is no too acid (Fatyma ,1980 and Short \& Spaulding ,2012). The present paper may be regarded as the first detailed morphological and ecological study on ferns in Iraq and Kurdistan However a series of many other investigations on ferns within the area will be stimulated in order to fulfill the existing gap of the knowledge on ferns and its distribution in Iraq and Kurdistan in particular.

Phyllitis is so variable that literally hundreds of varieties have been named in the past. Many almost indistinguishable from each other. Any ramble through a colony will reveal forms that deviate to greater or lesser degree from the normal plant.

Grounds (1982) have revealed more than 25 varieties of this fern. Undoubly more detail taxonomic study will reflect quite few varieties of Phyllitis in Kurdistan and even Mallakan .

\section{Refrences}

AL- Maqdamy, B.A.(2008). Anatomical and cytological study on the fern Salvinia natans . Msc thesis Univ, of Baghdad. College of Ibn-ALhaithum pp:120.(in Arabic)

AL- Nima, B.A.(2003). Astudy on some bryophytes frome different regions in north of Iraq. phD. Thesis College of science Mausl univ, pp: 187. 
AL-Mayah, AA,. Al-Saddi, AS, and Abdullah, NS.(2016). A new generic recorde (Azollz, Salviniaceae ) to the aquatic pteridoflora of Iraq . Int. J .Appl. Rese. Vol. 16 : 21-23.

AL-Rawi, A, (1988). Poisnous plant of Iraq . Ministry of Agriculture . Iraq. Baghdad.

AL-Rawi, A. (1988). Wild plants of Iraq with their distribution . Ministry of Agriculture . Iraq. Pp:232.

American Public Haelth Asossciation (APHA). (2005). Standerd methods for water and wast water analysis . $20^{\text {th }}$ Ed. Pp:724.

Benniamin A .(2011). Medicinal ferns of North Eastern India with spcial reference to Aranachal Pradesh. Indian J of traditional knowledge . vol. 10(3) : 516-522.

Chakravarty, HL. (1976). Plant welth of Iraq .Vol.1. Ministry of Agriculturare . Iraq. Pp: 505.

Charly, Lowe, and Michel ,Bumflic,.(2002). Ferns of England (natural history of ferns ) vol, $6(3): 4-8$.

Aziz, F H. (2017). Survey of pterigophytes from Iraq and Iraqi Kurdistan region . Mezopo. Envir. J. Vol. 3(2) : 40-68.

FT,Parsone. (1961). How to Know the ferns. Dover publ.Inc. New York . $2^{\text {nd }}$ Ed. Pp:

Futyma, RP. (1980). The distribution and ecology of Phyllitis scolopendrium in Michigan . American Fern J .70 (3): 81-87.

G Sathiyaraj, T Muthkumar, and K C Ravindaran.(2015). Ethnomedicinal importance of ferns and fern allies traditionally used by tribal people of palani hills , Westren Ghts, South India. Journal of medicinal herbs and ethnomedicin . 1(1): 4-9.

Goerg, ER, and Jhon, R. (2013). Methods for soil,plants, and water analysis : Amnual fore West Asia and North African regions . $3^{\text {rd }} \mathrm{Ed}$. pp:244.

Guest, E. and AL-Rawi, A. (1966). Flora of Iraq. Introduction to Iraqi flora. Vol. 1 . Ministry of Agriculture . Iraq. Pp:

Ibraheem,I,Y,(1989). Anatomical, cytological,comparative study on Marsilia copensis . Msc thesis Univ. of Baghdad. Colleg of education for pure science pp: 120 (in Arabic ).

Marsh, AF,. Amone, GA, and Borman, BT. (2000). The role of Equisetum in recycling in Alaskan shrub wetland . Journal of ecology . 88. PP:999-1011.

Maulood, BK,. AL-Khasraji, TO, and Ismail , AM. (2016). A study on pteridoflora of Kurdistan of Iraq : A morphological study and distribution of Equisetum L. (Horse tail) in Iraqi Kurdistan . Int. J of Emerging Technologies in Computinonal and Applied Science . 18(1): 78-84.

Maulood,B. K,. Sulaiman, N. I,.and AL-Bassam ,I.T.(1990). Algae and Archegoniats . Univ. of Baghdad,colleg of education Ibn-al haithum pp: 589

Michel, JT. (2003). Ferns of American garden . Timber press.

R, Grounds .(1974). Ferns . pelhambook. pp:327.

R, Grounds. (1982) . Ferns. Kambridge press .pp:422. 
Salih, AS . (2014). Buldding the flora of Kurdistan region of Iraq . M.Sc thesis Univ.of Reading U. K.

Smith, AR,. Kathlen, MP,. Erie, S,. Pera, K, and Paul,GW. (2006). A classification for extant ferns . Journal of Taxon 55(3): 705-731.

Smith, GM. (1955). Cryptogamic Botany. Vol. 2. McGraw Hill publication New York.

Townsend , CC and Guest, E.(1966). Flora of Iraq . Vol. 2 .Ministry of Agriculture Baghdad. pp:184 . 